\title{
Indo-Omani Relations in the Reign of Sultan Taimur Bin Faisal Al Busaidi (1913-1931 AD)
}

\author{
Dr. Mahmmoud Muhammad Al-Jbarat, Assistant Professor \\ Modern and Contemporary History, Al-Balqa'a Applied University \\ Amman University College for Financial and Administrative Sciences, Jordan \\ E-mail: aljbarat@yahoo.com
}

$\begin{array}{lc}\text { Received: June 8, } 2011 & \text { Accepted: September 9, } 2011 \quad \text { Published: January 1, } 2012 \\ \text { doi:10.5539/ach.v4n1p77 } & \text { URL: http://dx.doi.org/10.5539/ach.v4n1p77 }\end{array}$

This article Materials was gathered during 2010-2011 in preparation to participate in the International Conference (Oman and India prospects and civilization) held at sultan Qaboos University from February 27th to March 1 st 2011 and the main Ideas were presented in Arabic.

\begin{abstract}
This paper relies on primary resources dealing with the history of Oman along with British documents, which are the most important materials that dealt with the situation in the region, in general, and in Oman in Particular, at a time when Britain had power, presence and military control over India through the Government of British India. At that time, Britain tried to open lines of communication and forge agreements with the Arabian Gulf countries in order to secure its control over this vital region and secure communications with its colonies in India.

This study focuses on the economic and commercial relations between the two countries including trade of spices, textile, weapons, slaves, dates and other goods, the currencies used in these commercial exchanges, and the volume of trade. It also explores the volatility of these relations in different periods.

The study also examines the social and cultural relations, mutual migrations, and military and political ties. In addition, it explores various aspects of reciprocal influence between the two areas in different periods and during turbulent times for the sultanate of Oman and the region, prior to, during and after the First World War. It investigates these relations from signing of the treaty of AL-Seeb in 1920 and the stabilization phase it created up to the end of the study period.

The study has reached a number of conclusions about the development of these relations and the factors influencing this development at a time when sultan Timor tried to maintain independence in running the country despite the British influence. It also focuses on how the sultan attempted to benefit from Britain's need to secure shipping lines by enhancing the sultanate's trade with India until India became the first economic and trade partner with the sultanate during this period. The sultan tried to maintain a friendly relationship with Britain and India, where his currency was mined and where he used to stay for recuperation.
\end{abstract}

Keywords: Oman, India, Contemporary history, Trade and economic relations, Sultan Taimur Bin Faisal Al Busaidi

\section{Introduction}

Indo-Omani relations have possibly not been studied during the reign of SULTAN TAIMUR AL BUSAIDI (1913-1931 AD) for the lack of sources on one hand, and sensibility of wiring modern and contemporary history on the other hand, as well as the absence of Arab and foreign researchers on such task.

Of these documents available are: British-Omani (records of Oman), reports of British Navy, annual economic reports on business of Oman, telegrams and reports on Arabian Gulf, Oman and Indo-British Government and its measures taken in Oman and India.

It is also included documents relevant to Arabian Sea and Arabian Gulf, Red Sea, Indian Ocean, and summaries for the control of British Navy on firearms trading and slave, movement of population, vessels, and goods from 
and to Oman.

This study tried to describe the Indo-Omani relations during this confused period prior, during, and after the First World War, at time while the area was under the British power through varied British documents, researches, and some Omani locally sources available.

Generally, study briefly reviewed the conjunctures in the region, overview on Sultan Taimur and his ruling period, and studied the Indo-Omani relations at various levels, including sub-headlines: Military, Trade of Firearms, Economic and trade relationships, and some tables prepared by the researcher based on sources concerning Indo-Omani Trade, Oman and its deviations as per fiscal years, and finally, cultural impact and exchange migrations of population.

\section{Preface}

During the study, water and shores of the Arabian Gulf were under the command of British Navy, managed by the East India Station (Note 1) which it was not to be used by local or international powers without the consent of the British Navy.

British documents indicated that the leadership of the British Navy in India, informed their leadership in Britain: "it would not allow, even to the British Royal Air Forces, to establish a temporarily stations-in any form-on the shores of Arabian Gulf, without the coordination and approval of the East India station on that"( Note 2).

British Navy showed its power by its reconnaissance squads over the Arabian Gulf for preventing and monitoring the trade of firearms and slave(Note 3 ), and it had not only to protect oil supplies, but also the pearling sites, trade lines between India, Pakistan and Gulf coasts, British officials, transport troops and supplies from and to India, transfer individuals recruited for Britain from and to India, including Somalis, Indians, in addition to the transportation of coal supplies from India to Muscat and the Arabian Gulf (Note 4).

Over the time, part of the Navy had been developed by efforts of British political agents and advisers in Arabian Gulf until became a saying, "British Government power, where British Navy exists, is true state of affairs".

British Navy was able to maintain stability, starting from East India Naval Company, and to the Royal British Navy. It was also able to ensure the imposition of treaties of alliance and peace in the region, however, it was negatively influenced by the health conditions of the areas that were under its power, that infection and contagious diseases, as malaria, were communicated, through its soldiers and sailors, from India to the Arabian Gulf (Note 5).

However, such Navy guaranteed the shipping lines, allowed the flow of trade between India and Oman, monitored it, and recorded all things related to such trade. British documents had shown special attention to exchanges of trade and deviations, and were a major source and an important economic, trade, military, social, and cultural relationships between India and Oman. During such period, correspondences of Oman were by Secretary of State for India (Note 6). British Staff and officers serving in Oman provided their reports and services for information (Note 7) besides to their working results to the Government of India. Vital strategic location of Oman at regional and international levels was an important component of calm and stability (Note 8) during the withdrawal of France from conflict on Oman in 1914, and none of any major countries, except it, tried to challenge British dominion over Oman (Note 9).

\section{Sultan Taimur Bin Faisal Al Busaidi (1886-1965 Ad)}

After the death of his father Sultan Faisal, on 4 October 1913, he took the reins of Sultanate, and had undertaken to reform the country and to eliminate social and government corruption (Note 10). He was a religious youth man, hoping to attain understanding with the internal opposition, as was very close to it (Note 11), but was forced to face such roused opposition. Breaking out of the First World War on 4th August 1914, led Britain to put strict controls on firearms trade (Note 12), financing sources for the Sultanate. Sultan Taimur faced German advertising, confirmed defeating Britain and allies in the war. Conviction that was established by continuance of war, confirmed that Britain would not be in a position to assist the Sultanate (Note 13).

Sultan had faced the attack of opposition movements on the House of 'Fillaj' near 'Matrah' on 11 January 1915, supported by Indian troops that were dropped in (Note 14). He faced the resistance to the death of Imam Salim bin Rashid Kharousi in July 1920. Agreement was signed with opposition movements 'Saib Agreement" on 25 September 1920.

For Sultan to handle the local situations, he has used a thousand of British-Indian forces to protect the capital city, after the withdrawal of opposition forces, while the budget-state was at the lowest levels(Note 15).He had to rely on British support, during he was experiencing the decline of general position besides to his illness. 
In March 1920, sultan left to India, met with Deputy Government of India (Mr. Wingate) and asked him to stay for hospitalization in (Dehra Dun) area on the versant of Himalayas (Note 16). During his residence, he accompanied by: Mr. Hamed Bin Faisal (sultan's brother), Mr. Mohamed bin Ahmed (Sultan's Secretary), Mr. Saif bin Bader (Gwadur Governor), Sheikh Saif bin Muslim (secretary of the Sultan), Faraj and Mabrouk (servants of Sultan), Mr. Fail (Servant of Mr. Hamid al-Faisal, and Sweid (servant of Matrah Governor) (Note 17).

During his stay in India, in the first of October 1920, Sultan formed his government in the "Masqat" of four ministers, then he come back to India in November 1920. He visited India several times, one of them he sailed to India on 28 November 1928; during of his stay in India, he had hoped that his son Mr. Said can rule country in best ways. Based on, he had pushed his son for higher education in Mayo College at "Ajmer / Rajputana", so he sent him to Baghdad when was 17 to learn Arabic language in an Arab country. At the death of the Prime Minister Mohamed bin Ahmed in July 1929, Sultan Taymour installed his son "Mr. Said" as "Prime Minister" to be well-skilled, at 18 years.

During the stay of Sultan Taimur in India, he was listening to the Resident British Political briefing in Oman about the current position (Note 18).

On 17 November 1931, the Sultan had transferred his throne to his son "crown prince" Mr. Said, and remained in India for four years later, and then came back to Muscat in 1945-1946 AD that was received in an exciting celebration (Note 19), but he preferred to return to India later that died in Bombay in 1965 (Note 20).

\section{In the Military and Firearms Trade}

Study period begins to oppose Sultan Taimur by the Sheikh Issa bin Saleh, and his supporters demonstrated against the actions of Sultan on the passage of weapons to areas controlled by Sheikh Issa(Note 21), and the British Navy appears to closely monitoring the coast of Oman, the situation has been described by a report dated on 6 January 1913 as follows: "There is no information about any weapons, or ammunitions which was dropped on the beach during the last week, and that that control process on weapons supplied to Oman is being followed up by Bushaher (Note 22), and that until February 1913, few of weapons were being traded, while few of guns and ammunitions is still sold in stores for a French people at "Matrah" (Note 23).

It was noted that the Sultan Taymour, due to the prevailing domestic situation, ordered the British Political Agent in Oman to provide the merchant "Ali Mousa" with 70.000 cartridges (ammunitions). The sultan was stood by such dealer; that disagreed with the British authorities when issued an order to deport him (Note 24) at time when British authorities noted that the weapons trade takes place in Bombay / India, through barter with coconut, or through bank transfers (Note 25).

Percy Cox, the Resident British Political in Arabian Gulf, suggested in a subsequent report to seconding a British officer, or choosing an Indian officer, or both, to create an armed-force of (300) man of Makran or India, to work as guards in Muscat, and to assist the British forces therein, that such forces expenses will be covered through increasing the tax revenues, or through any revenues available (Note 26).

During the attack of tribes on Muscat in October 1914, it was found that the British-Indian forces strongly defended against Muscat, although it has been severely damaged after the attack of tribal on Roy, especially after the allowing of throwing bombs group (102) for some tribesmen to have some guns. However, the Sultan gave his deep thanks for the assistance of British government during the disorders (Note 27). A need for the formation of a permanent force of Indian army in Beit Alfllaj is exist to prevent the recurrence of such acts, and to achieve the independence of Muscat before the Government of India.

In 1914, twenty-two men of Omani' police forces were trained on woodwind brass musical instruments by the maestro "Goan", who was brought from India, that trained them at the opposite side of Muscat(Note 28).

During 1914, the British authorities noted that the Sultan Taymour insists on the development of Sultanate power particularly from people of Oman without coordinating of consulting with Britain. He declared opening the recruitment of these forces in "Muscat" and "Mattrah" regions, to be the local forces Muscat's, Mattrah's, Sedab, Kalabwa, Reyam, and anyone from their inhabitants"(Note 29), to be trained and independent, with efficient not less Indian forces or militias guarded the Indian border.

As a result, the British authorities examined the possibility of forming a military unit in Muscat from Makran coast, or Baluchistan, or Baluchians living in Oman, or Arabs of Oman, or Somalis under the command of British or Indian officers in the British army. Although the British government approved on the formation of these forces in March 1914, prepared a long-term plan for recruiting, training, managing, and financing of these forces and determine their obligations, and providing a British conception about the salary range of officers, 
other British ranks, and Indian officers recruited by the Indo-British government. Government of India had studied the possibility of these forces to be a police to Muscat, Mtrah, and to the Royal Sultanate Palace (Note 30), that their budget will be handled by the Sultan himself, and their main objectives are to replace the local forces of Sultan for protecting the capital against tribesmen. It is also examined to grant Indian forces soldiers serving in Oman (Batta) or allowance of Muscat, however, these plans, which seemed clashing between the Sultan Taimur needs, and what is being panned by British government, that had been postponed due to First-World-War conditions(Note 31). British-Navy was sending, those captured for dealing with weapons within Arabian Gulf, to India (Note 32).

On 11 January 1915, a force supported by the Imam, were aroused near Matrah, which was fought by a thousands of Indo-British troops. After this trial, military authorities in India considered the preceding proposal to create a force of 300 man is very little, that recommended to be 500 man on Oman's budget, however, this proposal has not been implemented as well.

In the course of First World War, British Navy had controlled the weapons trade from and to Oman, noted, at firsts of the war, that such business was widespread in Oman, but passing by Dubai; quantities had been big, but under the control of British authorities in Dubai, and also by Oman through the intelligence officer, and police officials, that procedures are being reviewed every three months (Note 33). Besides, most of the Eastern India navy visited the port of Muscat in 1915.

Despite of weapons trade popularity, it was noted that it were just an individual weapons, which only 67 gun were captured during the periods from 21 January until April 1914.

During 1915, no evidences were existed regarding arms trade from and to Oman, perhaps due to the revealing conditions of First World War. However, since 1916, the reports of the British Navy in Arabian Gulf, Red Sea, and India had focused on the visits made by officials of navy to ports and politicians, inspected the troops, course of military operations, political movements in the region. Reports, during that period, were written or signed by Vice-Admiral, that became extended including the important developments, and did not concentrated on the details concerning small arms-trade, but on the condition of British forces and its movements, number of enemy forces in Hijaz to Aden, Yemen, Arabian Gulf, Iraq, India, Pakistan, and Sri Lanka. On 19 July 1916, at east of India, British Navy Commander suggested, "that there is no need for more visits of British-Navy to ports of the (Persian) Gulf, as it was in the last year" (Note 34).

In 1917, LBH Haworth, British Political Residing in Muscat, made a proposal for recruiting 1000 man on both sides of Arabian Gulf's coast, but, at the end, the Government of India refused to do so. However, Sultan Taimur tried, in the same year, to recruit a temporary special force from Baluch and blacks led by Turkey (Note 35), but the British troops in Oman, reinforced by Indo-British troops of Indian-Brahmins sect dwelling in Basra on 28 May of such year (Note 36).

\section{Following the First World-War}

The idea of recruiting troops in Oman from India remained standstill until 1920, while Muscat levy Corps were recruited from Sistan and Indian-Baluchistan (Note 37) of (248) men of officers and militants led by the British officer, Captain E. D. McCarthy, which arrived at Muscat on 19 April 1921, however, it has been a force well-trained, organized, and prepared to hold its obligations in Oman. Such force was trained by Captain McCarthy and well-skilled Indian officers. It has been accepted by the Sultan as it wasn't belonged to any tribes, and thereby don't clash, through its tribe's loyalties, with the Sultan's purposes. It was armed with 250 short-guns "Mark 7" of Indian Government weapons-stock. It had three Indian officers and 150 Indian from other ranks (Note 38).

These troops were camped in tents, and then moved to facilities built in green oases on a space behind the house of Al-Fallaj, ten miles from Muscat. It had been nice facilities. As these forces mostly of Baluch, recruited by contracts for three years, weather was very bad, some of them infected with malaria, anemia, and other diseases until September 1921, however, it was better to be replaced by Omanis. By March 1922, only 56 Sistanians might have continued in such force, and on 2 May 1922, all of them had left Oman (Note 39).

While Captain McCarthy indicated in his report on such forces, "it is proper to enlist Baluches in Muscat". He noted that they were eager to serve in such forces, willing to recruit their brothers and relatives (Note 40). Resident Political official in the Arabian Gulf, Mr. Trever also realized the increasing number of local Omanis, Baluch living on the coast of Oman, Makran's Baluch, and Omani Arabs among these forces. Captain "Scott" was the commander of Indian forces in the Arabian Gulf, and inspects the troops constantly.

In 1927, it was decided to end the usual training course of the Indian Army in Muscat included three Indian 
officers. In October 1928, Resident Political official in the Arabian Gulf had reported to the Secretary of the Government on the troops of Muscat appreciated "the high services for the following Indian officers that served in these forces:

- Subedar Major Fateh khan, was of the 20 bowmen, and served for twenty-four year.

- Subedar Fateh khan, was besides to the twenty bowmen, and served in the Muscat for four years and a half.

- Jemadar Mohammed Ibrahim with ten of Baluches (Note 41).

\section{Economic and Trade Relationships}

In first decade of twentieth century, it was noted that there is an increasing contraction in the size of India's trade with Oman, but it was promising and started to expand during the period of study (Note 42). At the beginning of Sultan Taimur term, Oman's foreign trade volume witnessed another drop with its neighbors in the Arabian Gulf for the benefit of trade booming with India and Europe, as a result of increasing the number of steam-trade vessels used among these ports (Note 43). There were 35 Indian merchants in Oman protected by Britain, while there were 10 Indian-dealers with ten million rupee; the size of their investment in Muscat, helping 4 British merchants in firearms and ammunition, representing the commercial agencies, and have houses and properties in Oman.

Pre-study period, volume of exchanged trade between Oman and India was 70.17.600 rupee, of which 43.25.000 rupee as Oman's imports from India; mainly rice mostly from Calcutta (24\%), firearms and ammunition (16.5\%), and cotton textiles nearly $(8.5 \%)$, spices $(4.5 \%)$, cotton yarn (2.5\%), silk and its productions (2\%), sugar and coffee $(2 \%)$ each, and some other grains (2\%). Whereas Oman's exports to India was 26.92 .600 rupee, including: dates (19.5\%), spices (10.5\%), dried fish, shellfish, dried lemon, and fresh fruit were (1\%) each (Note 44$)$. The following table showing the numbers, that we were able to obtain from the British documents; all regarding trade-exchanging between Oman and India during the study period.

Reviewing these figures, it is found that the trade volume of Indo-Oman has increased comparing with Foreign Omani trade of $48.3 \%$ at the beginning of the study period, which means that nearly half of foreign Omani trade was with India, and has developed to be two-thirds of such trade, then to three-quarters in the first year of First-World-War (1914-1915). Following, it was started to fall back during (1916-1918) due to war conditions, then, returned to thrive rating $94.91 \%$ during (1921-1922), to which was firmed at high rates between $87 \%$ and declined to $84 \%$ during (1923-1927).

It was observed that this trade has declined in size over the years 1928 and 1929 between $71 \%$ and $75 \%$ as was affected by global recession, and then, despite the recession, it was jumped to $88.57 \%$ in (1929-1930).

Then it was returned to drop to $61.70 \%$ in (1930-1931), and $58.42 \%$ in (1931-1932). Decline in the volume of bilateral trade was due to other competitors on a trade partnership with Oman, in particular the rival of the United States of America and Japan.

At the first of study period, British documents indicated that Muscat is the capital and main port of the Sultanate of Oman and a port of coal (Note 45). For its location, surrounded by large rocky hills, it hadn't locally business contacts with Oman, but as it is on two miles long from Matrah, which was the local commercial hub of Oman, It had been supplying Matrah with their needs of goods, exporting Oman's goods across the sea.

As British documents confirming on the commercial competition of Germany, Britain preparedness against this competition, British India S.N. Co. had built beacons from Bushehr to Linga, Bandar Abbas, Bahrain, and Dubai, however, the Government of India concluded that the Germany's goal was political rather than commercial (Note 46).

In Muscat, many types of money were used for local-trade and with India during the study period, that I arranged it in order of importance, and level of trading as follows: (i) U.S. Maria Teresa's dollar, (ii) Silvers struck by Oman's Sultan in 1895, and was re-minted in India through the times of Sultan Faisal and Sultan Taimur, (iii) British gold pound, and (iv) Indo-British currency. It was used to replace these currencies of different discounts inside Oman.

On the other hand, value of goods in Oman's foreign trade was calculated by black and white of (Mohomadis), computed a fake value of currency that was (Gaj) (Note 47). At the beginning of the study period, there was a fluctuation in exchanging rate at local market of Oman lasted three years (1914-1916). Despite the circumstances of First-World-War, import and export had continued until the end of 1915. However, these operations had been adversely affected by a list of prohibitions announced by Indo-British Government, ban on weapons import in particular, new cargo regulations for steam-ships, in addition to the inability of commercial vessels to reach 
Muscat coming from India or Europe. It had been observed that commercial ships weren't able to load Bengali rice, which was the main import of Muscat's from India, and Sultan Taymour also wasn't able to import anything of his belongings (Note 48 ).

1915 was very bad (Note 49), however, more than half of all Oman's foreign trade was with India (Note 50). The total trade of Oman was Rs. 9,038,270 decreasing up to $12 \%$ from the last year. Decreasing of European spices imports by $10.2 \%$ noticed as well. Nonetheless, the coast of Arabian Peninsula and India had taken a share thereof. During such year, exports of Oman to India were as: 5 tons of dates, dried-fish (8.12.000), pearl (780), fruits (12.80), and Omani lemon (12.80). It was observed that the Arab commercial vessels Ltd., managed by "Turner Morrison", hadn't done their commercial functions as usual during such year.

Fiscal of (1915-1916) witnessed many ups and downs in the dollar of "Maria Theresa" in Indian trade, even though the exchange fees, which were charged in India, known Hindi, was still taken in Mohammedis not in rupees. Based on, revenues of Oman from spice-trade were great at this year.Customs Office in Muscat was managed and monitored by the government of Indo-British for His Highness the Sultan (Note 51). Two of such office officials, during 1915, were Indians, the first was "Sayed Abu Saleh", his father was former officer in the Indian Army, and the second "Mohammed Riamoo" from Khoja, who became a British citizen (Note 52). It was noticed that the trade of firearms and ammunition's revenues had completely eliminated from the business budget. Most of goods were imported from India, while some had been returned from Zanzibar and Arabian Gulf to Oman that and hadn't been monitored and recorded (Note 53).

As a result of decreasing trade in Oman, number of Indian officials informed the Resident British Political that many of Indian traders would leave Oman, if you did not show any signs of improvement in the country. The Resident British Political against reported, "the prosperity of Muscat is based on navigation and commercial services, that the latest have declined due to war circumstances, and inability to move freely between the Oman and the coast (Note 54).

As usual, Oman had a lion share of India's trade, "It was normal", according to British documents, added, "However, the trade of Oman is bad to worse, recorded shipments have decreased at the rate of $29 \%$ ", as it was noted that the commercial shipments, via sailing ships, have doubled during this year due to the circumstances of war and fears of commercial steam ships (Note 55).

British India Steam Navigation Company had kept up sending express mail with Muscat from and to India, but the ordinary mail had been interrupted since December 1915 (Note 56).

In 1917, Soor AL-Madina Port, 95 miles to the south of Muscat, began direct prosperous trade with India, Zanzibar, and East Africa. By recession of Oman's foreign trade, port of Muscat was no longer the head center of trade, brokerage business, or weapons-trade. As a result of increased freight charges during 1917, due to circumstances of First-World-War, and disappearance of firearms and ammunition imports from business-budget, most of trade had been concentrated on the exchange of Omani dates with Indian cotton products (Note 57).

British authorities refused the requests of the Sultan to appoint Indian officials at Omani customs or as government secretarial related money and commerce with India fearing of Arabs opposition (Note 58). As mentioned in the documents, such opposition might be for the desire of Indo-British Government to dominate on customs revenues on one hand, interference in the Sultan's ability to borrow from Indian traders on other hand.

During the fiscal year (1918-1919), the rate of Maria Teresa's dollar exchange was dropped due to globally silver low price, domestic seasonal demand, impact of Bahrain's pearls market, and also Muscat was under bad weather because of the increased temperatures most of the year. The most prominent and Oman's imports: rice, coffee, sugar, wheat, and flour. Oman had exchanged its exports of dates with India by coffee and cotton products. Indian Navigation Company hadn't visited the port of Muscat as usual, because there wasn't any place for steam shipping services due to War, and there were no reports on Soor trade volume with India, or reports related to freight rates to India (Note 59), while Indo-British Government had provided a loan to Oman in 1918, to repay their debts (Note 60) after trade crisis, high prices, and inability of the government's for solving the debts and interests (Note 61).

\section{Post-War Period}

Importance of Muscat's Port was increased during the (1919-1920), especially in the area of trade in Arabian Gulf, after it had become, due to its geographical location, an important center for trade exchange for Indian-African business. For peace, and movement of commercial vessels grew normal, other ports in Oman were flourished as "Sahar" and "Matrah", besides to "Soor" and some small ports. No reports were provided to the Indo-British Government concerning the trade volume of "Soor" port, while the British documents confirmed 
that this port made (80) trips during (1919-1920) to ports of Basra, India and Africa.

Trade of Oman had also thrived with India due to the increasing demand for Omani dates, dried fish, and pomegranate in India. For the unavailability of trade, or European traders making business between Europe and the Arabian Gulf, control of Arab traders, British citizens, and Indians of both Albanian and Khoja on importing and exporting processes of such trade.

It was noted that the British Documents, for the first time in 1919, had begun to conduct statistics for Oman's trade in sterling pounds, also noted that the Bureau of Omani Customs employed Egyptian citizens for the first time (Note 62). This year had recorded an increase in the volume of trade summed (£43.315). However, Indo-British Government had provided Oman with another loan in 1920 to repay its debts, and organized the tax process (Note 63 ).

British reports had noticed no significant changes on Muscat's trade with India since 1920 to 1922, while it was noticed that the foreign trade of Oman was dropped by (£53.400) However, Oman Trade with India reflected a very high percentage amounted to $94.91 \%$ of Oman's foreign trade volume (Note 64). During this period, countries began to appear competing India in the volume of trade with Oman; Japan and the United States, respectively.

Oman exported dates to India had increased to (£12.186), and the British reports noted that most of Muscat's houses had been abandoned or turned into ruins due to quit of their owners (Note 65), perhaps for internal migration to Matrah and Soor.

During (1921-1922), India's share in Oman's trade continued high, but imports of Oman from Indian rice dropped, which attributed, by British documents, for the increment of smuggling; while Omani exports had increased for high level of following export products: sardines increased by (£7.700), dates (£20.20), Omani Lemon (£7.700), and fine sugar by (£10.000) (Note 66).

In fiscal year (1923-1924), despite the continuing decline of Muscat's port and their people, it remained the capital of Oman and the HQ of government. Exports of Oman had increased about (£15.265), and noted that exports of Omani Dates to India dropped for the dates trade with the United States (Note 67).

In 1923, Sultan Taimur undertook to Indo-British Government not to grant any rights for using oil in Oman before consulting the British Political Agent in Muscat, as well as the consent of Delhi Government thereto (Note 68). Anglo-Persian Oil Company Ltd. Had hoped to start working on oil exploration in Muscat during the autumn of 1925 (Note 69), but the results of preliminary conversations and surveys weren't fruitful up to 1937 (Note 70).

Foreign trade of Oman, during (1924-1925) showed high moderate levels in the total volume than the last year by $9 \%$, which was due to the increased trade with India and the United States as well. British Documents manifested that (115) vessel had been anchored the ports of Oman during (1924-1925); (106) of which came from India.

Muscat had maintained its position as HQ of the government in (1925-1926). Customs revenue was the main source of government, while "Matrah" kept maintaining its position as trade center within Oman. Volume of Oman foreign trade had increased by $10 \%$. Trade volume increment with India was for the growth imports of rice, while exports of Omani dates dropped for the continuing lack of rain in the last years. During, Indian trade to the port of Muscat also dropped. Therefore, Indian traders living in Muscat, running 95\% of the total trade within, their trade had dropped that some of their shops and businesses had been empty. Port of Matrah had maintained its position for the association with domestic trade of Oman. Ports of Oman had received (119) vessels, (110) of which from India, and most Omani exports were through steam ships (Note 71).

In (1926-1927), foreign trade of Oman declined by 30\% due to the reduction of Omani imports from rice, sugar, some cereals, coffee, cotton, rope, and yarn from India, declining exports of Omani dried and humid dates to India, was for the scarcity of rainfall for the second year respectively; with the observation that rain had fallen in the ends of 1927 to improve dates production. Meanwhile, contribution of India in Omani foreign trade kept high (84.58\%), which the ports of Oman received (117) vessel, (108) of which came from India. Oman imports had decreased by $27 \%$ due to the strict control of the Persian Customs Authorities on sugar imports from Oman, which was supplied against exporting (Cuch) to avoid paying taxes (Note 72).

British reports had noticed that the cash in Oman was little during (1927-1928), and that there was no request within Oman on good Indian rice, which only few imported from Calcutta, while Oman, during this year, imported (Bulk) rice from Karachi as less expensive than Calcutta, and required by poor people of Muscat and Oman. And that there are no imports of rice directly from Rangoon, and some quantities of rice come indirectly 
through Pompeii and falls within the Indian exports. (126) ship had been docked in the ports of Oman was, (116) of which came from India.

In (1928-1929), India was still the first trade partner of Oman despite the drop of Indian rice imports by both steamships and sailboats. Conversely, imports of Pakistani loosed rice were increased, which (130) vessel anchored to Omani ports, (112) came from India (Note 73).

In 1929, following the approval of Sultan, a British Wireless Station were established serves the aircraft over the Arabian Gulf, Arabian Sea, flights from Muscat to Basra and Karachi. Indo-British Government and the India Office in London were granted the approval on the establishment of this station that provided the necessary equipments (Note 74).

Imports of Oman were declined via steamships and sailboats by (£26.622) in (1929-1930), and imports of Oman from Indian rice were also decreased for Pakistani loosed rice. And exports of Omani dates fallen as well by $17.70 \%$ than last year ( $£ 110.347$ to $£ 90.801$ ). This was due to poor rains and locust invasions. Meanwhile, Omani ports received, until 31 March 1930, about (140) steamships of different countries had loaded (335.091 tons). Ships carrying the British flag had loaded (315.205 tons). Meanwhile, ports of Oman received about (89) vessels of various countries, including (87) came from Indo-British (Note 75).

During (1930-1931) the volume of Omani trade kept dropping by (£44.171), the importations of Pakistani rice continued instead of Indian rice. A number of (287) ship reached the Omani ports loading (33.422 tons), (254) of which from India British.

Fruitful rains had fallen on Oman during this year, wheat planted widely, but the parasites and rust wiped out the crop before harvesting. British reports noticed that some Omani tribesmen had imported machinery to grind the Jaggery; unrefined brown sugar made from palm extract.

Researcher noted that those British documents indicated that the cotton textiles manufactured in Oman had been exported for the first time most likely in (1930-1931) (Note 76), that was no reference on this in the following year, which within decline continued in volume of Omani foreign trade; and India remained the first trade partner of Oman during (1931-1932). British Documents had begun, since this year, using rupee as a currency in monitoring the size of Omani foreign trade, and confirmed the total value in sterling pounds (Note 77).

During 1932, British documents separated between navigation trade and overland trade in Oman, and monitored the volume of trade in Oman, which was activated by paved roads, and small and medium cars, and tippers (Note 78).

\section{Cultural Impact and Population Migrations}

Arabic was still the dominant language in Oman, while some in Muscat and Matrah, during the study period, speak Farsi, Baluchi and Hindustani; the latter were often understood by everyone (Note 79), while business correspondence, and telegraph service were in English language (Note 80). Mail and telegraph were established in Muscat by the government of Indo-British.

While British documents and Omani local sources did not record a wide immigration of Omani people to India, the impact of economic and trade relationships and Omani cultural with India for encouraging Omanis individually in the migration to India could not be ignored. However, the British documents recorded infected patients were sent from Oman to India for treatment, especially rabies (Note 81).

On the other hand, while population of Muscat, for example, was in (1914-1915) around (10.000), but during the beginning of the study period Oman had Indians in groups, and Muscat had two hundred men, fifty women, and some children of Hindus as staff and importers of goods, rice, and coffee from India. They were exporting dates and silverwares from Oman, while they had the best home-gardens in outskirts of Muscat (Note 82), but had kept the connection with India that they were coming back to it at social events and marriage. Most Hindus of Muscat came from "Kuch mandvi" (Note 83), while others stayed in Matrah, and some established small ports on the coast.

Muscat had ten sects of Khoja; Asha'ra party (Note 84), which their largest gathering was in "Almataria". They had founded this place in the late first decade of the twentieth century, did not return to India, some of them might ignore to register himself, or retain his Indian nationality, that became citizens of Muscat (Note 85). Some of Khoja resided Soor Alloatien, Berket Sahhar, Khabourah, and Masnaa, however, we did not find any reference to their number during the study period.

It was noted that most British citizens' were residing in Matrah, some of them belongs to Khoja sect, and half of the last were British citizens, while the other half didn't record themselves as British citizens, but Arabs, however, 
a large number of those were British citizens as per law and as their ancestors citizenship. British authorities were discussing the issue to consider them as British citizens by granting them the citizenship until 1918 .

It is worth noting that Muhammad Fazil (died on 4 August 1915), the Deputy of U.S. Consul in Muscat (1914-1915), was a citizen in the Indo-British government, and was an agent of British India Steam Navigation Company (Note 86).

When Major "Howarth" attended to Seeb in 1920, half number of his guards were from Brahmins (Note 87). Fifty men of Task Skilled (117) led by Captain Pearson were in service of Mr. Wingate, the British Political Resident in Muscat when he arrived Seeb in 1920. British authorities protected the Indian traders in Muscat (Note 88) and applied the Indian laws over all Indians residing in Oman (Note 89).As perfumes were weighted with Tolla; a unit of weight equal to (11.664) of Indian gram, but Maria Theresa dollars was used to weight ambergrisit products (Note 90).

\section{Conclusion}

This study aimed at focusing, by historical perspective, on Indian-Oman relations during the reign of Sultan Taimur bin Faisal Al Busaidi; through available sources, mostly British documentary sources goes back to such period, which was able to be reviewed.

This study concluded a set of findings, most remarkable that the relations of Indian-Oman, during the period of study, were made under the influence and control of Great Britain and through the Government of Indo-British. These relations were reinforced in military, economic, trade, and migrations of people areas, in a clear development, since the early days of Sultan Taimur until (1930-1931).

While Oman utilized from its relations with India in various area, but the size of its exports to India was less than imports, as the United States and Japan competed India in its relations with Oman at the end of the study period, which affected on Oman's trade with India for the benefit of these two countries.

\section{References}

Allen, C. H. Jr. (1987). Oman: The Modernization of the Sultanate, West view press, Boulder. Colorado, Croomhelm. London and Sydney.

Arabian Gulf and Red Sea Naval Reports, 1820-1960. (1993). Volume 11. Archive Edition.

Arabian Gulf Oil concessions, 1911-1953. (1989). Documents from India Office, London, Recording the Negotiations and Agreements for the first Land-based oil Concisions in Kuwait, Bahrain, Qatar, the Trucial States and Muscat and Oman. Archive Editions, Printed by Redwood Burn Ltd., Trowbridge, and Bound by Green Street Bindery, Oxford.

Bailey, R. W. (1988). Editor, Records of Oman, 1867-1947. Volume III, Historical Affairs. Archive Editions.

Burdett, A. L. P. (1994). Editor, The GCC States: National Development Records; Defense, 1920-1960. Volume 3 , Trucial States, Muscat and Oman. Archive Editions.

Burdett, A. L. P. (1994). The GCC States: National Development Records: Civil Aviation, 1920-1962. Volume 2; Bahrain, 1923-1935, Kuwait, 1920-1934, Muscat, 1920-1934, Qatar, 1927-1938, Trucial States, 1931-1938, archive Editions.

Burdett, A. L. P. (1995). Editor, Records of the Persian Gulf Pearl Fisheries, 1857-1914. Vol. 2, Archive Editors, Crown Copyright Material from the Public Record Office and the Oriental and India Office Collections of the British Library, London.

Burdett, A. L. P. (1996). Editor, The GCC States: National Development Records: Communications and Transport, 1860-1960. Volume 5, The United Arab Emirates, Persian Gulf Waters, Oman, Archive Editions, England, Hobbs the Printers Ltd, Totton Hampshire, Oxford.

Graz, L. (1983). The Omanis Sentinels of the Gulf. Longman, London and New York.

Landin, R. G. (1967). Oman since 1856 AD. Commandeered \& Destiny.

Lorimer, J. G. (1994). Gazetteer of the Persian Gulf, Oman and Central Arabia, Volume II (Geographical and Statistical), Hanjam-Na'alah, Archive Editions.

Persian Gulf and Red Sea Naval Reports, 1820-1960. (1993), Volume 9. Archive Editions.

Persian Gulf and Red Sea Naval Reports, 1820-1960. (1993), Volume 10. Archive Editions.

Peterson, J. E. (1978). Oman in the Twentieth Century; Political Foundations of an Emerging State, Croom Helm, 
London. Barnes and Noble Books, New York, (A division of Harper and Row Publishers, Inc.

Philips and Windel. History of Oman, Translated by: Mohammad Amin Abdallah, Oman Sultanate. Ministry of National Tradition and Culture, 1401 AH/1981 AD.

Rush, A. de lacy. (1991). Editor, Ruling Families of Arabia, Sultanate of Oman: The Royal Family of Al Bu Sa'id, Vol. 2, Archive Editions, England, Redwood, Oxford.

The Persian Gulf Administration Reports, 1873-1947. (1986). Volume VII, Vol. VIII, Vol. IX, Archive Editions. Burn Ltd., Trowbridge, Oxford.

The Persian Gulf Trade Reports, 1905-1940 (1987). Muscat Vol. 1, Vol. 2, Archive Edition.

\section{Notes}

Note 1. Arabian Gulf and Red Sea Naval Reports, (1820-1960), Volume 11, (1929-1931), Archive Edition, 1993. p. 624. P.G. N.R., Vol. 11 (will be referred to later).

Note 2. From: Comander in Chief, East India Station, to: The Secretary of the Admiralty, London, 20th Jun, 1930. See: Ibid., Vol. 11, p. 624-625.

Note 3. P.G.N.R., Vol. 11, p. 608.

Note 4. Persian Gulf and Red Sea Naval Reports, (1820-1960), Volume 10, (1916-1929), Archive Editions, 1993. p. 236. P.G. N.R., Vol. 10 and P.G.N.R., Vol. 11, p. 617,620-621. (will be referred to)

Note 5. See P.G.N.R., Vol. 10, p. 233-235, p. 244.

Note 6. Burdett, A.L.P., The GCC States: National Development Records: Civil Aviation, (1920-1962), Volume 2; Bahrain, 1923-1935, Kuwait, 1920-1934, Muscat, 1920-1934, Qatar, 1927-1938, Trucial States, 1931-1938, archive Editions, 1994, p. 258. C.A. (will be referred to later)

Note 7. Burdett, A.L.P., Editor, The GCC States: National Development Records; Defense (1920-1960), Volume 3, Trucial States (1929-1939), Muscat and Oman, (1920-1939), Archive Editions, 1994, p. 208, 227. Defense (will be referred to later)

Note 8. Graz, Liesl, The Omanis Sentinels of the Gulf, Longman, London and New York, p. 170.

Note 9. Landin, Rober Geran, Oman since 1856AD, commandeered \& Destiny, 1967.

Note 10. Allen, Calvin H.Jr., Oman: The Moderniza of the Sultanate, West view press, Boulder. Colorado, Croomhelm, London and Sydney, p. 60.

Note 11. R.O.O., Vol. III, p. 3.

Note 12. Rush, A. de lacy, Editor, Ruling Families of Arabia, Sultanate of Oman: The Royal Family of Al Bu Sa'id, Vol. 2, Archive Editions, England, Redwood, Oxford, 1991, p. 11, 20. R.F. (will be referred to)

Note 13. R.O.O., Vol. III, p. 8.

Note 14. R.F., p. 28.

Note 15. R.O.O., Vol. III, p. 4.

Note 16. Bailey, R.W., Editor, Records of Oman (1867-1947). Volume III, Historical Affairs, (1913-1947), Archive Editions, 1988. p. 17. R.O.O. Vol. III. (will be referred to later)

Note 17. R.O.O., Vol. III, p. 161. From: Political agent Muscat, to: Delhi, 14th March 1920.

Note 18. P.G.A.R., Vol. VII, p. 60.

Note 19. R.F., Vol. 2, p. 237-253.

Note 20. For Sultan activities and trips after his throne transferring, see Ibid, Vol. 2, p. 217-234.

Note 21. Persian Gulf and Red Sea Naval Reports, (1820-1960), Volume 9, (1913-1918), Archive Editions, 1993, p.3. P.G. N.R. Vol. 9. (will be referred to later)

Note 22. P.G.N.R., Vol, 9, p. 5.

Note 23. Ibid., Vol, 9, p. 9.p.151.

Note 24. The Persian Gulf Administration Reports, (1873-1947), Volume VII, (1912-1920), Vol. VIII, (1921-1930), Vol. IX, (1931-1940), Archive Editions, Printed by Burn Ltd., Trowbridge, Oxford, 1986, Vol. VII, p. 104. P.G.A.R; (will be referred to later. 
Note 25. Ibid., Vol, 9, p. 151.

Note 26. P.G.A.R., Vol. 9, p. 154.

Note 27. R.O.O., Vol. III, p. 10.

Note 28. Peterson, J.E.; Oman in the Twentieth Century; Political Foundations of an Emerging State, Croom

Helm, London, Barnes and Noble Books, New York, (A division of Harper and Row Publishers, Inc. p. 104.:

Peterson (will be referred to later).

Note 29. R.O.O., Vol. III, p. 654., see also Sultan announcement, P. 655.

Note 30. R.O.O., Vol. III, p. 663 \& 667.

Note 31. Ibid., Vol. III, p. 660, p.670.

Note 32. P.G.A.R., Vol. VII, p. 42,p.647.

Note 33. P.G.N.R., Vol. 9, p. 191.

Note 34. Ibid., Vol. VII, p. 43,p.191,p.260.

Note 35. Peterson, p. 91.

Note 36. P.G.A.R., Vol. VII, p. 44.

Note 37. R.O.O., Vol. III, p. 705.

Note 38. Defence, p. 213.

Note 39. R.O.O., Vol. III, p. 732,p.648.

Note 40. Defence, p. 221.p.227,p.242.

Note 41. Defence, p. 251.

Note 42. Lorimer, J.G., Gazetteer of the Persian Gulf, Oman and Central Arabia, Volume II (Geographical and Statistical), Hanjam-Na'alah, Archive Editions, 1994. p. 1188. G.P.G (will be referred later)

Note 43. P.G.A.R., Vol. VII, p. 103.

Note 44. P.G.P., p. 1187.

Note 45. The Persian Gulf Trade Reports, (1905-1940), Muscat 1; (1905-1925), Vol. 2 (1925-1940), Archive Edition, 1987, (1914-1915), p. 1, M.T. (will be referred to later).

Note 46. Burdett, Anita L.P., Editor; Records of the Persian Gulf Pearl Fisheries, (1857-1914), Vol. 2 (1925-1940), Archive Editors, Crown Copyright + Material from the Public Record Office and the Oriental and India Office Collections of the British Library, London, 1995, p. 541-544.

Note 47. M.T., Vol. 1, (1914-1915), p. 1-2.

Note 48. Ibid., Vol. 1, (1914-1915), p. 3-4.

Note 49. P.G.A.R., Vol. VII, p. 67.

Note 50. M.T., Vol. 1, (1914-1915), p. 5,p.4-5.

Note 51. Ibid., Vol. 1, (1915-1916), p.1-2.

Note 52. P.G.A.R. Vol. VII, p. 64.

Note 53. M.T., Vol. 1(1915-1916), p. 3.

Note 54. P.G.A.R., Vol. VII, p. 67.

Note 55. M.T., Vol. 1, (1915-1916), p. 3.

Note 56. Ibid., Vol. 1, (1915-1916), p. 3.and M.T., Vol. 2, (1932-1933), p. 3.

Note 57. Ibid., Vol. 1, (1916-1917), p. 4.

Note 58. P.G.A.R., Vol. VII, p. 42.

Note 59. M.T., Vol. 1, (1918-1919), p. 1-4.

Note 60. P.G.A. R., Vol. VII, 1920, p. 62.

Note 61. Landen, p. 467.

Note 62. M.T., Vol. 1, (1919-1920), p. 1-4. 
Note 63. Philips \& Windel, History of Oman, Translated by: Mohammad Amin Abdallah, Oman Sultanate, Ministry of National Tradition and Culture, 1401 AH/1981 AD, p. 180.

Note 64. M.T., Vol. 1, (1921-1922), p. 1.

Note 65. Ibid., Vol. 1, (1919-1920), p. 2-3. and M.T., Vol. 1, (1921-1922), p. 2.

Note 66. Ibid., Vol. 1, (1922-1923), p. 3.

Note 67. M.T., Vol. 1, (1923-1924), p. 1-2.

Note 68. Landin, p. 474.

Note 69. M.T., Vol. 2, (1924-1925), p. 2.

Note 70. Arabian Gulf Oil concessions (1911-1953), Documents from India Office, London, Recording the Negotiations and Agreements for the first Land-based oil Conssitions in Kuwait, Bahrain, Qatar, the Trucial States and Muscat and Oman, Archive Editions, Printed by Redwood Burn Ltd., Trowbridge, and Bound by Green Street Bindery, Oxford, 1989. See pp. 32, 47, 67, 76, \& 83.

Note 71. M.T., Vol. 2, (1924-1925), p. 1-3.

Note 72. M.T., Vol. 2, (1926-1927), p. 2-3.

Note 73. Ibid., Vol. 2, (1928-1929), p. 2.

Note 74. Burdett; A.L.P., Editor, The GCC States: National Development Records: Communications and Transport (1860-1960); Volume 5, The United Arab Emirates, Persain Gulf Waters, Oman, Archive Editions, England, Hobbs the Printers Ltd, Totton Hampshire, Oxford, 1996. p. 239-250.

Note 75. M.T., Vol. 2, (1929-1930), p. 2-3.

Note 76. Ibid., Vol. 2, (1930-1931), p. 2-3.

Note 77. M.T., Vol. 2, (1931-1932), p. 3.

Note 78. Ibid., Vol. 2, (1932-1933), p.2-3.

Note 79. Ibid., Vol. 2, (1914-1915), p. 4.

Note 80. Ibid., Vol. 2, (1915-1916), p. 2.

Note 81. P.G.A.R., Vol. VII, (1931), p. 37.

Note 82. G.P.G., Vol. 2, p. 1185.

Note 83. M.T., Vol. 1, (1916-1917), p. 3.

Note 84. G.P.G.,p. 1187.

Note 85. M.T., Vol. 1, (1916-1917), p. 3.

Note 86. P.G.A.R., Vol. VII, p. 50, p.68.

Note 87. R.O.O., Vol. III, p. 16.

Note 88. G.P.G., p. 1187.

Note 89. M.T., Vol. 1, (1915-1916), p. 2. and M.T., Vol. 1, (1916-1917), p. 4.

Note 90. Ibid., Vol. 1, (1914-1915), p. 2. 
Table 1. Show the volume of mutual-trade of Oman and India

\begin{tabular}{|c|c|c|c|c|c|c|c|}
\hline Fiscal year & $\begin{array}{c}\text { Grand } \\
\text { volume } \\
\text { of foreign } \\
\text { trade }\end{array}$ & $\begin{array}{l}\text { Trading } \\
\text { with } \\
\text { India }\end{array}$ & $\begin{array}{l}\% \text { trade } \\
\text { with } \\
\text { India }\end{array}$ & Exports & Imports & $\begin{array}{l}\text { Increase or } \\
\text { decrease in } \\
\text { balance of } \\
\text { trade }\end{array}$ & Notes \\
\hline $1912-1913$ & Rs.11475426 & Rs.5542805 & $48.3 \%$ & 2431227 & 3211578 & $-7.8 \%$ & $\begin{array}{c}\text { Nearly half of foreign } \\
\text { trade was with India } \\
(48.3 \%)\end{array}$ \\
\hline 1913-1914 & Rs.10189584 & Rs.7001514 & $8.71 \%$ & 2171889 & 4829625 & -2657736 & $\begin{array}{l}\text { More than one third of } \\
\text { foreign trade was with } \\
\text { India }\end{array}$ \\
\hline 1914-1915 & Rs.9038270 & Rs.7003253 & $77.48 \%$ & 2609172 & 4391081 & $-17.82 \%$ & $\begin{array}{c}\text { More than three } \\
\text { quarter of foreign } \\
\text { trade was with India }\end{array}$ \\
\hline $1915-1916$ & Rs.6467741 & Rs.5214081 & $80.63 \%$ & 3095462 & 3095462 & $-29 \%$ & $\begin{array}{l}\text { More than four fifth of } \\
\text { foreign trade was with } \\
\text { India }\end{array}$ \\
\hline $1916-1617$ & Rs.42000000 & Rs.2960629 & $69.16 \%$ & 69.19 & - & 2551749 & $\begin{array}{l}\text { Foreign trade of Oman } \\
\text { is declined due to } \\
\text { increasing taxes }\end{array}$ \\
\hline 1917-1918 & $£ 323815$ & - & - & - & 160321 & $74 \%$ & $\begin{array}{l}\text { Report of Oman's } \\
\text { trade is lost from } \\
\text { British documents }\end{array}$ \\
\hline 1918-1919 & $£ 7984313$ & $£ 6351758$ & $79.59 \%$ & 2082935 & 284588 & +1798 & $\begin{array}{c}\text { More than three } \\
\text { quarters of foreign } \\
\text { trade was with India }\end{array}$ \\
\hline 1919-1920 & $£ 575603$ & $£ 455557$ & $79.15 \%$ & 2082935 & 246318 & -18366 & $\begin{array}{l}\text { Foreign trade of Oman } \\
\text { is declined by } 69 \%\end{array}$ \\
\hline $1920-1921$ & $£ 914910$ & - & - & 209239 & 502387 & -500295 & $\begin{array}{l}\text { Report of Oman's } \\
\text { trade of } 1920-1921 \text { is } \\
\text { lost from British } \\
\text { documents }\end{array}$ \\
\hline 1921-1922 & $£ 885506$ & $£ 840395$ & $94.91 \%$ & 350656 & 480739 & 67505 & $\begin{array}{l}\text { Nearly } 87 \% \text { of foreign } \\
\text { trade was with India }\end{array}$ \\
\hline 1922-1923 & $£ 627360$ & $£ 550414$ & $87.72 \%$ & 251779 & 398535 & -146756 & $\begin{array}{l}\text { Nearly } 87 \% \text { of foreign } \\
\text { trade was with India }\end{array}$ \\
\hline 1923-1924 & $£ 559855$ & $£ 483158$ & $86.33 \%$ & 149412 & 334747 & -185335 & $\begin{array}{l}\text { Nearly } 86 \% \text { of foreign } \\
\text { trade was with India }\end{array}$ \\
\hline $1924-1925$ & $£ 612883$ & $£ 519829$ & $83.35 \%$ & 159057 & 452572 & -293515 & $\begin{array}{l}\text { More than four fifths } \\
\text { of trade was with } \\
\text { India }\end{array}$ \\
\hline $1925-1926$ & $£ 673817$ & $£ 570003$ & $84.59 \%$ & 175164 & 394839 & -219675 & $\begin{array}{l}\text { More than four fifths } \\
\text { of trade was with } \\
\text { India }\end{array}$ \\
\hline 1926-1927 & $£ 474202$ & $£ 401104$ & $84.58 \%$ & 111328 & 280776 & -169448 & $\begin{array}{l}\text { More than four fifths } \\
\text { of trade was with } \\
\text { India }\end{array}$ \\
\hline 1927-1928 & $£ 518944$ & $£ 394019$ & $75.92 \%$ & 100617 & 293402 & -192785 & $\begin{array}{c}\text { More than three } \\
\text { quarters of trade was } \\
\text { with India }\end{array}$ \\
\hline $1928-1929$ & $£ 510120$ & $£ 366188$ & $71.80 \%$ & 107599 & 258580 & -150981 & $\begin{array}{l}\text { More than one third of } \\
\text { trade was with India }\end{array}$ \\
\hline $1929-1930$ & $£ 459446$ & $£ 315957$ & $88.57 \%$ & 100098 & 214998 & 114900 & $\begin{array}{l}\text { More than one third of } \\
\text { trade was with India }\end{array}$ \\
\hline $1930-1931$ & $£ 415275$ & $£ 268680$ & $61.70 \%$ & 8340618 & 185632 & -102226 & $\begin{array}{l}\text { Figures related to } \\
\text { import and export are } \\
\text { not clear in the } \\
\text { documents, that were } \\
\text { decreased in the last } \\
\text { year by } £ 44171\end{array}$ \\
\hline 1931-1932 & $£ 2180777$ & $£ 1274010$ & $58.42 \%$ & 941851 & 228481 & -1343 & Decreased by $£ 19317$ \\
\hline
\end{tabular}

